\title{
The Generalist Model: Where do the Micro and Macro Converge?
}

\author{
Shari E. Miller \\ Carolyn J. Tice \\ Diane M. Harnek Hall
}

\begin{abstract}
Although macro issues are integral to social work, students continue to struggle with the acquisition of knowledge and skills pertaining to larger systems. Educators have developed innovative methods to integrate learning across systems of various sizes however it appears an imbalance persists. This challenge is supported by baccalaureate student responses to a social work program evaluation. Four years of data from 295 undergraduate students revealed that they felt less prepared to practice with larger, macro systems. Changes in curriculum to reflect collaboration and holism, and more research are needed to adequately provide macro learning and macro practice opportunities within the generalist model and in the context of the current socioeconomic-political environment.
\end{abstract}

Keywords: Generalist model; macro practice; macro learning; social work education

Research findings indicate that social work students have notably more learning opportunities to work with individuals, families, and groups than they do to work with communities and organizations (Butler \& Coleman, 1997; Hymans, 2000; Koerin, Reeves, \& Rosenblum, 2000; Raber \& Richter, 1999). Of particular concern is the reluctance of many students to consider involvement in social action through activities such as lobbying, legal advocacy, and neighborhood organizing (Kasper \& Wiegand, 1999). As such, social work students may be hampered in their abilities and/or willingness to develop the skill sets necessary to identify and utilize organizational and community strengths to empower clients and effect systems change (Koerin et al., 2000).

\section{REVIEW OF THE LITERATURE}

\section{The Generalist Model}

The socio-political climate of the late 1960's and 70's encouraged social work educators to evaluate the content and conceptual frameworks of social work practice (Bisno, 1971; Iacono-Harris \& Nuccio, 1987; Pincus \& Minahan, 1973; Teare \& McPheeters, 1970). The result of this evaluative effort was the emergence of the generalist model, a method of practice that integrates casework, group work, and community organization, and focuses on the interaction between persons and their environments. According to Compton, Galaway, and Cournoyer (2004), the notion of person-in-the-environment allows for change strategies directed toward (a) individuals, (b) the environment, and, (c) the interface between the individual and his/her environment (Iacono-Harris \& Nuccio, 1987, p. 80). For Johnson (1998), the generalist

Shari E. Miller, Ph.D., is an assistant professor at the School of Social Work, University of Georgia, Athens. Carolyn J. Tice, DSW, is Associate Dean and Program Chair of the University of Maryland Baltimore County Department of Social Work. Diane M. Harnek Hall, Ph.D., is an assistant professor in the Department of Family Studies and Community Development at Towson University.

Copyright @ 2008 Advances in Social Work Vol. 9 No. 2 (Fall 2008), 79-90 
approach requires that social workers recognize the variety of systems that interact with one another and that interact with people (Meenaghan, Gibbons, \& McNutt, 2005). The generalist model provides the overarching structure for the undergraduate social work and foundation year graduate curriculum continuum.

Several generalist perspectives have emerged including those of Tolson, Reid, and Garvin (2002) who present a task-centered approach to generalist practice; Miley, O'Melia, and Dubois (2008) who suggest an empowerment approach; and McMahon (1990; 1996) who presents a problem-solving approach. These models all include a structure and process that direct the social worker to approach each client and situation with openness to the use of a variety of techniques and levels of intervention (Waites, 2000). Whatever the perspective, generalist practice is multi-method, multi-theoretical, and transferable across diverse fields of practice, settings, and populations. Further generalist practice uses problem-solving to assess and intervene in micro, mezzo, and macro systems. Though there are some definitional differences between and across social work programs at the undergraduate and graduate levels, there appear to be universal points of agreement, including that generalist practice:

1. Uses the person-in-the-environment perspective as the theoretical foundation for assessments and interventions.

2. Involves assessments that support interventions involving micro, mezzo, and macro practice.

3. Assumes that social workers will have diverse roles such as educator, advocate, counselor, planner, organizer, and administrator.

4. Integrates practice, policy, and research through roles and functions.

5. Conceptualizes practice as comprised of engagement, assessment, planning, implementation, and evaluation (Gelman \& Mirabito, 2005; Kirst-Ashman \& Hull, 2008; Miley, et al., 2008; Poulin, 2000).

\section{Macro Practice}

Macro practice is intrinsic to the generalist model, so how is this level of intervention defined? According to Long, Tice, and Morrison (2006), macro practice "involves the ability to see and intervene in the big picture, specifically with larger systems in the socioeconomic environment” (p. 3). Macro practice can include collaboration with clients to strengthen and maximize opportunities for people at the organizational, community, societal, and global levels. Many social workers would argue that the profession's particular attention to state, national, and international issues of importance to clients, distinguishes social work from other helping professions (Glisson, 1994; Long et al., 2006).

Historically the term indirect practice was used to denote the elements of macro practice. Unlike the term direct practice, which characterized specifically face-to-face contact with clients, indirect practice was used to refer to social work's commitment to change-efforts at the environmental level with a focus on societal issues such as poverty, 
housing, and healthcare (Pierce, 1989). Thus, macro activities, by definition, extend beyond individual interventions but are often based on needs, problems, issues, and concerns identified in the course of working one-on-one with clients (Netting, Kettner, \& McMurtry, 1998).

Larger systems are typically the focus of macro level work. According to Rothman, Erlich, and Tropman (1995), there are three key arenas of macro intervention: communities, organizations, and small groups. Kirst-Ashman and Hull (2008) state that integrating generalist social work practice with macro systems involves interventions that (a) maintain positive community social processes, (b) develop and restore social processes that can contribute to human development and functioning, and (c) empower individuals and small systems to influence the larger systems affecting people's lives (pp. 116-117).

Other writers focus on the policy context in which macro intervention occurs as policy change is integral to communities and organizations (Fisher, 1995; Flynn, 1992; Jansson, 1994). As stated by Netting, et al. (1998), fundamental to macro practice and subsequent broad based change is "an understanding of overriding ideologies and values that influence local, state, and national politics" (p.7). The strengths and empowerment models have enhanced the macro perspective by focusing on elements such as positive attributes and social power essential to achieving positive change (Meenaghan et al., 2005; Saleebey, 2005; 2003).

The literature related to social work education includes a variety of different strategies to enrich macro content, some of which engage students in the context of the classroom, others through the field experience (Koerin et al., 2000). One identified approach requires students to engage in an in-depth community study or needs assessment within the context of a macro practice class (Hymans, 2000; Sherraden, 1993). Bordelon (2003) describes a practice class in which students create a universitycommunity partnership along with their instructor, and Huber and Orlando (1993) define an innovation that engages students in an in-class, hypothetical project to challenge the bounds of their interventive thinking. Other approaches invite students to engage in advocacy (Butler \& Coleman, 1997; Raber \& Richter, 1999), and still further approaches are designed to address the nature of field placements, field assignments and field instruction (Allen \& Shragge, 1995; Kasper \& Wiegand, 1999; Koerin et al., 2000; Siu, 1991; Skolink \& Papell, 1994; Wolk, Pray, Weismiller, \& Dempsey, 1996).

Social work educators conclude that macro practice necessitates that students both produce and consume research (Walsh, 1998). Examples of assignments that integrate a macro perspective with research are community assessments, organizational analyses, and surveys (Dunlap, 1993; Grinnell \& Kyle, 1977; Plionis, 1993). Thus macro practice much like micro and mezzo intervention uses critical thinking to engage in (a) problem identification and definition, (b) study, exploration, and data collection, (c) differential assessment, planning, and intervention, (d) evaluation, (e) termination, and (f) follow-up (Meenaghan et al., 2005, p. 9). 


\section{STUDENTS’ EVALUATION OF MACRO LEARNING}

To better understand the student experience of learning macro practice several years of program evaluation data were analyzed. A program evaluation was developed in accordance with the Council on Social Work Education standards by faculty at a large mid-Atlantic baccalaureate social work program. Questions were designed to help evaluate the quality and effectiveness of (a) the overall baccalaureate social work program, (b) the field education setting and experience including evaluation of the agency, field instructor and specific assignments within the agency, and (c) the field liaison component of the program. Face validity was confirmed through faculty development, and internal consistency was analyzed and found to be high (Cronbach's $\alpha$ $=.97$ ). However no other tests of validity or reliability were administered.

The sample included all graduating baccalaureate social work students for the years 2004 through $2007(n=312)$. Completed program evaluations were collected from a total of 295 students (95\% response rate) at the end of the spring semester during their graduating year. A majority of the respondents were female (91.3\%) and white (59.8\%). The other racial groups represented were African American (22.0\%), Hispanic (10.4\%), Asian American (3.5\%), bi/multiracial (1.2\%), and other (3.1\%). The respondents ranged in age from 20 to 63 years, with a mean age of 28 years. The gender and racial characteristics of the study's respondents are similar to those of social work students across the nation (Lennon, 1999; Knight, 2002).

A MANOVA analysis was utilized to compare data from year to year (2004 through 2007) - no significant differences on overall program evaluation findings emerged. In the four years of program evaluation the same two areas of inquiry reflected a noticeable pattern of responses related to the level of system. Responses to two areas of questioning (feelings of preparedness and extent of experience) illustrate the differences in students' perspectives regarding varying system levels.

\section{Macro Experience in Field Assignments}

The program evaluation asked the respondents to evaluate on a 5-point Likert scale (" 1 " = low; "5" = high) the extent of experience gained in field education assignments that integrated generalist practice across client systems. Such assignments pertained to individuals, groups, and community involvement. As described in Table 1, respondents reported a high degree of experience with field assignments involving individuals $(M=$ 4.43; $S D=.961)$. Assignments with groups $(M=3.35 ; S D=1.46)$ yielded a lower level of experience, yet still more experience noted than that pertaining to community assignments $(M=3.24 ; S D=1.29)$. The findings from the evaluation suggest that, for the evaluation of assignments in this sample, the larger the client system the lower the level of experience among students. 
TABLE 1: What was the extent of your experiences in assignments with: (1 low through 5 high)

\begin{tabular}{crcc}
\hline Rating & Individuals & Groups & Communities \\
\hline 1 & $2.4 \%$ & $18.2 \%$ & $12.4 \%$ \\
2 & $3.4 \%$ & $10.7 \%$ & $16.5 \%$ \\
3 & $9.2 \%$ & $18.9 \%$ & $25.1 \%$ \\
4 & $19.1 \%$ & $22.7 \%$ & $26.5 \%$ \\
5 & $65.9 \%$ & $29.6 \%$ & $19.6 \%$ \\
\hline
\end{tabular}

\section{Preparedness to Use Knowledge and Skills in Macro Practice}

Respondents were asked to consider their overall preparation in generalist social work including both class and field education, and to rate on a 5-point Likert scale (" 1 " = not at all; "5" = very much) for each item how well the program prepared them to appropriately use the knowledge and skills of generalist social work practice with individuals, groups, and communities. As indicated by Table 2 a majority of respondents reported feeling very prepared to work with individuals $(M=4.46 ; S D=.702)$, while responses of very prepared were much lower in work with groups $(M=3.80 ; S D=1.06)$ and communities $(M=3.18 ; S D=1.05)$. Most graduates from this program seem to feel less prepared to work with larger systems at graduation.

TABLE 2: How well has the program prepared you to practice with: (1 not at all through 5 very much)

\begin{tabular}{crcc}
\hline Rating & Individuals & Groups & Communities \\
\hline 1 & $.3 \%$ & $4.2 \%$ & $5.9 \%$ \\
2 & $1.0 \%$ & $5.9 \%$ & $18.5 \%$ \\
3 & $7.0 \%$ & $24.8 \%$ & $38.3 \%$ \\
4 & $35.9 \%$ & $36.0 \%$ & $26.1 \%$ \\
5 & $55.7 \%$ & $29.0 \%$ & $11.1 \%$ \\
\hline
\end{tabular}

It is important to note that the lack of clarity and consistency in the language used to discuss macro interventions and generalist practice in the literature had bearing upon the 
questions asked in the program evaluation. Similar to a limitation noted by Koerin, et al., (2000) the program evaluation reflected ambiguity when asking students to describe their macro learning experiences in both the classroom and field placement. Also the findings discussed are descriptive of this sample of graduates. Though the sample may reflect the demographics of the population of baccalaureate social work graduates it may not be representative of the population, which limits generalizability.

\section{DISCUSSION OF PROGRAM EVALUATION FINDINGS}

The four years of evaluation data reported in this article support the challenges of integrating macro learning in the social work curriculum. Of particular concern is students' perceived imbalance between the micro and macro in the curriculum content and field education experiences. Though the authors do not believe that a polarization of micro and macro practice is a productive construction for the social work profession, the authors recognize that an imbalance exists in the described baccalaureate program, and from what is gathered from the literature, this imbalance exists pervasively (Butler \& Coleman, 1997; Huber \& Orlando, 1993; Hymans, 2000; Kasper \& Wiegand, 1999; Koerin et al., 2000; Raber \& Richter, 1999; Siu, 1991; Wolk et al., 1996). Over the past 100 years a debate has persisted within the profession that encourages the idea that micro and macro social work are two mutually exclusive orientations (Haynes, 1998). By polarizing practice in this way the fundamental values and ideas at the heart of social work become muted. What identifies social work as a distinct profession is its focus on the possibilities for change in the person and the environment. By polarizing micro and macro practice social work becomes about the person in one vacuum and the environment in another.

Over the course of the four years of evaluation the social work program discussed in this article introduced pedagogical and experiential methods that attempted to integrate micro practice with macro practice through lectures, in- and out-of-class assignments, case studies, and continuing education sessions. However these attempts have not yet resulted in any significant change in students' evaluations - clearly other barriers to integrating micro with macro practice exist.

\section{Barriers to Integration of Micro and Macro Practice and Learning}

The enormous changes in the fabric of the nation's social welfare and social service delivery systems are of particular significance to social work education. Welfare reform legislation, devolution of policy responsibility and involvement in social service delivery to states and localities, the increasing privatization of social services, agency budget cuts and downsizing, the dominance of managed care in both health and mental health arenas, and economic globalization have influenced the practice of social work and by extension social work education (Jarman-Rohde, McFall, Kolar, \& Strom, 1997; Reisch \& JarmanRohde, 2000).

Within this socio-political climate there is an enormous impact upon the availability and quality of field placements and subsequently a great deal of shifting and increasing demands placed on field education (Jarman-Rohde et al., 1997). According to Jarman- 
Rohde et al. (1997) for agencies the focus on productivity, accountability, and managed care has created barriers to providing social work students with appropriate placements and/or adequate supervision. Field instructors often carry heavy caseloads, are required to do more paper work, and have less time to spend supervising students. At the same time agency expectations regarding the types and breadth of student assignments increase parallel to agency needs. Students are assigned increasing numbers of clients with complex and multiple problems, yet agencies are also concerned about the potential liability associated with having students on-site (Jarman-Rohde et al., 1997).

It has been documented that other barriers to making macro learning assignments available to students in field education, though related to the large-scale shifts as discussed above, are also traceable to the orientations of agencies and field instructors. "Most agencies fail to validate macro practice tasks as worthy aspects of workers' defined responsibilities, while the individual workers serving as field instructors possess neither the competence nor the confidence to model and teach macro level practice responses” (Butler \& Coleman, 1997, p. 65). Although this position points to current realities, and might even explain the strikingly consistent program evaluation findings, it unfortunately fosters the culture of micro-macro encampment within the profession and social work education.

\section{The Future of Macro Learning}

The complex environment of social work practice requires social work educators to reassess the profession's fundamental purpose. Historically social work has supported the dynamics of individual, community, and societal change. Given the centrality of change to social work, Reisch and Jarman-Rohde (2000) suggest that:

An expectation of change can provide social work educators with a framework to comprehend and potentially influence that environment, and thereby nourish a sense of hope and possibility in an era shrouded with a growing sense of powerlessness and resignation (p. 212).

Reflective change is integral to this article's focus. Program revisions are needed to enhance macro learning content and to better integrate micro practice with macro practice at the same time as the profession struggles to redefine its focus in an increasingly complex and contentious social and political climate.

A number of social work educators suggest that the need for change in curriculum and field education can be embraced as an opportunity (Abramowitz, 1998; Bisno \& Cox, 1997; Jarman-Rohde et al., 1997; Reisch \& Jarman-Rohde, 2000; Weil, 1996). Such change values a model of social work education and practice that fosters a sense of leadership and empowerment in clients, students, educators, field instructors, and in our collective selves. A model of social work that invites meaningful change across levels of interactions encourages not only students, but also practitioners and educators, to consider their actions in the context of environments. A reflective stance that encourages a view of the environment from within might encourage students, field instructors, and classroom educators to see both what is up close and what might be a bit further away. Expanding and enhancing content that connects micro and macro theory with practice 
requires faculty to ask questions as part of a dialogue with students, field instructors, and each other. Some of these questions are:

1. In what ways does the "use of self" offer opportunities for re-organizing how the macro can be found in and around the micro?

2. How do the values and principles of social work complement and/or conflict with the national and international socio-political climate?

3. Does the generalist social work curriculum include content that supports not only analysis of societal issues like oppression and poverty but also a call for collective action that leads to peace, social justice, and social change?

4. What is the role of the international and/or the nontraditional field placement in generalist social work education?

5. How can social work programs collaborate with agencies and communities to provide students with macro learning opportunities?

6. To what degree do social work educators, field instructors, and professional organizations model macro change efforts?

Although these emerging questions appear divergent in some ways, and although they each require extensive dialogue to fully address, they share some common ground and interlocking themes. Reflectivity, collaboration, and holism undergird the above avenues of inquiry. In keeping with the work of Ruffolo and Miller (1994) the above questions point to the need for university and agency collaboration and partnerships to reciprocally inform curriculum development. Effective learning relies on exchange of ideas, resources, and energy to teach practice skills in an increasingly diverse community of social work agencies. Further, another ingredient of collaboration embedded in the questions is that of social work educator as activist. By this we mean that, in order to teach macro skills in an integrative way, the questions imply that the instructor be an active participant in the learning process in and outside of the classroom. The practice experience gained and shared by the instructor encourages students to reflect upon their skill acquisition in a mutual learning environment (Ringel, 2003). Finally the challenge of teaching macro skills in an integrated fashion underscores the need for a multi-method holistic teaching approach in which students actively engage with readings, research, case studies, multimedia resources, and social action opportunities that capture both domestic and international large scale settings (Dewiest \& Roche, 2001). Using an array of teaching approaches encourages students to understand and apply macro practice from different perspectives and by doing so bridges the gap between recognizing problems, needs and strengths, and designing strategies for systematic change.

\section{CONCLUSION}

The program evaluation discussed in this article suggested that over a period of four years undergraduate social work students rated their macro learning experiences as less satisfactory than their micro ones. This consistent imbalance underscores the need to examine the generalist curriculum as well as field experiences that involve the acquisition 
of skills and knowledge related to macro practice. Future research is needed to examine approaches to enhance macro learning including agency and community collaborations and in-class teaching innovations. The language of generalist practice might need to be further clarified to best undertake future research. Research should also include measurement of students' macro skill development; evaluation of students' opportunities to gain practical experience in organizing, community assessment, and advocacy; and assessment of the inclusion of macro content across the generalist curriculum.

Ideally this article and others like it will generate a dialogue within the profession regarding macro experiences in generalist social work and where the micro and macro converge. Given that all clients and agencies are influenced by their communities, as are all social workers, the understanding of and skills to effect broad-based change are critical to practice across all levels of intervention. Change as a unifying construct makes social work, be it direct service in a clinical setting or grassroots organizing in a community, the unique profession it is.

\section{References}

Abramowitz, M. (1998). Social work and social reform: An arena of struggle. Social Work, 43, 512-526.

Allen, H. S., \& Shragge, E. (1995). Community-based field placements: Recent innovations. In G. Rogers (Ed.), Social work field education: View and visions (pp. 92-105). Dubuque, IA: Kendall/Hunt.

Bisno, H. (1971). A theoretical framework for teaching social work methods and skills, with particular reference to undergraduate social welfare education. In F. Lowenberg \& R. Dolgoff (Eds.), Teaching of practice skills in undergraduate social welfare and other helping services (pp. 72-88). New York: Council on Social Work Education.

Bisno, H., \& Cox, F. (1997). Social work education: Catching up with the present and the future. Journal of Social Work Education, 33. Retrieved on October 12, 2005, from EBSCOhost database.

Bordelon, T. D. (2003). People first: A case study in partnering with the community. Journal of Baccalaureate Social Work, 8, 147-161.

Butler, S. S., \& Coleman, P. A. (1997). Raising our voices: A macro practice assignment. Journal of Teaching in Social Work, 15, 63-80.

Compton, B. R., Galaway, B., \& Cournoyer, B. R. (2004). Social work processes $\left(7^{\text {th }}\right.$ ed.). Pacific Grove, CA: Brooks/Cole.

Dewiest, M., \& Roche, S. E. (2001). Teaching about human rights in social work. Journal of Teaching in Social Work, 21(1/2), 137-155.

Dunlap, K. M. (1993). A history of research in social work education 1915-1991. Journal of Social Work Education, 29, 293-300.

Fisher, R. (1995). Political social work. Journal of Social Work Education, 31, 194-203. 
Flynn, J. P. (1992). Social agency policy: Analysis and presentation for community practice. Chicago: Nelson-Hall.

Gelman, C. R., \& Mirabito, D. M. (2005). Practicing what we teach: Using case studies from $9 / 11$ to teach crisis intervention from a generalist perspective. Journal of Social Work Education, 41, 479-494.

Glisson, C.A. (1994). Should social work take greater leadership in research on total systems of service? Yes. In W. Hudson \& P. Nurius (Eds.), Controversial issues in social work research (pp. 155-159). Boston: Allyn \& Bacon.

Grinnell, R. M., \& Kyle, N. S. (1977). A model for bridging the gap between undergraduate research and practice. Journal of Social Work Education, 13(3), 30-36.

Haynes, K. S. (1998). The one hundred-year debate: Social reform versus individual treatment. Social Work, 43, 501-509.

Huber, R., \& Orlando, B. (1993). Macro assignment: Think big! Journal of Social Work Education, 29. Retrieved on November 5, 2005, from EBSCOhost database.

Hymans, D. J. (2000). Teaching BSW students community practice using an interdisciplinary neighborhood needs assessment project. Journal of Baccalaureate Social Work, 5, 81-92.

Iacono-Harris, D. A., \& Nuccio, K. E. (1987). Developing the macro pool: Turning undergraduates on to macro practice. Administration in Social Work, 11, 79-86.

Jansson, B.S. (1994). Social policy: From theory to policy practice $\left(2^{\text {nd }}\right.$ ed.). Pacific Grove, CA: Brooks/Cole.

Jarman-Rohde, L., McFall, J., Kolar, P., \& Strom, G. (1997). The changing context of social work practice: Implications and recommendations for social work educators. Journal of Social Work Education, 33. Retrieved on October 18, 2005, from EBSCOhost database.

Johnson, L. C. (1998). Social work practice: A generalist approach $\left(6^{\text {th }}\right.$ ed.). Boston: Allyn \& Bacon.

Kasper, B., \& Wiegand, C. (1999). An undergraduate macro practice learning guarantee. Journal of Teaching in Social Work, 18, 99-112.

Kirst-Ashman, K., \& Hull, G. (2008). Understanding generalist practice (5 ${ }^{\text {th }}$ ed.). Chicago: Nelson-Hall.

Knight, C. (2002). Teaching generalist social work practice: Students’ perceptions of the importance of the instructor's practice experience. Journal of Teaching in Social Work, 7, 93-111.

Koerin, B. B., Reeves, J., \& Rosenblum, A. (2000). Macro-learning opportunities: What is really happening out there in the field? Journal of Baccalaureate Social Work, 6, $9-21$ 
Lennon, T. (1999). Statistics on social work education in the United States: 1998. Alexandria, VA: Council on Social Work Education.

Long, D., Tice. C. J., \& Morrison, J. (2006). Macro social work practice: A strengths perspective. Belmont, CA: Thomson Brooks/Cole.

McMahon, M. (1990). The general method of social work practice: A problem solving approach ( $2^{\text {nd }}$ ed.). Englewood Cliffs, NJ: Prentice Hall.

McMahon, M. (1996). The general method of social work practice: A generalist perspective. Boston: Allyn and Bacon.

Meenaghan, T. M., Gibbons, W. E., \& McNutt, J. G. (2005). Generalist practice in larger settings: Knowledge and skills concepts. Chicago: Lyceum Books.

Miley, K. K., O’Melia, M., \& Dubois, B. (2008). Generalist social work practice: An empowering approach ( $6^{\text {th }}$ ed.). Boston: Allyn $\&$ Bacon.

Netting, F. E., Kettner, P. M., \& McMurtry, S. L. (1998). Social work macro practice. New York: Longman.

Pierce, D. (1989). Social work and society: An introduction. New York: Longman.

Pincus, A., \& Minahan, A. (1973). Social work practice: Model and method. Itasca, IL: F. E. Peacock.

Plionis, E. M. (1993). Refocusing undergraduate research training: Making conceptualization experiential. Journal of Teaching in Social Work, 7, 49-61.

Poulin, J. (2000). Collaborative social work: Strengths-based generalist practice. Itasca, IL: F. E. Peacock.

Raber, M., \& Richter, J. (1999). Bringing social action back into the social work curriculum: A model for "hands-on" learning. Journal of Teaching in Social Work, 19, 77-91.

Reisch, M., \& Jarman-Rohde, L. (2000). The future of social work in the United States: Implications for field education. Journal of Social Work Education, 36, 201-21.

Ringel, S. (2003). The reflective self: A path to creativity and intuitive knowledge in social work practice and education. Journal of Teaching in Social Work, 23(3/4), 1528.

Rothman, J., Erlich, J. L., \& Tropman, J. E. (1995). Tactics and techniques of community intervention ( $3^{\text {rd }}$ ed.). Itasca, IL: F. E. Peacock.

Ruffolo, M. C., \& Miller, P. (1994). An advocacy/empowerment model of organizing: Developing university-agency partnerships. Journal of Social Work Education, 30(3), 310-316.

Saleebey, D. (Ed.). (2005). The strengths perspective in social work practice ( $4^{\text {th }} \mathrm{ed}$.). Boston: Allyn \& Bacon. 
Saleebey, D. (2003). Power in the people: Strengths and hope. Advances in Social Work, 1, 127-136.

Sherraden, M. S. (1993). Community studies in the baccalaureate social work curriculum. Journal of Teaching in Social Work, 7, 75-88.

Siu, S. F. (1991). Providing opportunities for macro practice in direct service agencies: One undergraduate program's experience. Arete, 16(2), 46-51.

Skolink, L., \& Papell, C. P. (1994). Holistic designs for field instruction in the contemporary social work curriculum. Journal of Social Work Education, 30. Retrieved on November 5, 2005, from EBSCOhost database.

Teare, R., \& McPheeters, H. (1970). Manpower utilization in social welfare. Atlanta: Southern Regional Education Board.

Tolson, E., Reid, W., \& Garvin, C. (2002). Generalist practice: A task centered approach ( $2^{\text {nd }}$ ed.). New York: Columbia University Press.

Waites, C. (2000). Assessing generalist problem-solving skills: An outcome measure. Journal of Social Work Education, 6, 67-79.

Walsh, J. (1998). A model for integrating research, practice, and field instruction in the undergraduate curriculum. Journal of Social Work Education, 17, 49-63.

Weil, M. O. (1996). Community building: Building community practice. Social Work, 41, 481-499.

Wolk, J. L., Pray, J. E., Weismiller, T., \& Dempsey, D. (1996). Political practica: Educating social work students for policymaking. Journal of Social Work Education, 32. Retrieved on October 24, 2005, from EBSCOhost database.

\section{Author's note:}

Address correspondence to: Shari E. Miller, Ph.D., School of Social Work, The University of Georgia, 209 Tucker Hall, Athens, GA 30602. E-mail: semiller@uga.edu. 